\title{
Quaternary ontogeny of a pampean 'laguna'
}

\section{Sedimentological and biological characteristics of Lobos Lake sediments, Argentina *}

\author{
Nauris V. Dangavs ${ }^{1}$ \& Adriana M. Blasi ${ }^{2}$ \\ ${ }^{1}$ Instituto de Geormorfologia y Suelos, Universidad Nacional de La Plata, Argentina; \\ ${ }^{2}$ Comisión de Investigaciones Cientificas de la Provincia de Buenos Aires, Argentina; Present address: Instituto \\ de Geomorfologia y Suelos, UNLP. Calle 3 Nro. 584, (1900) La Plata, Argentina
}

Accepted 29 December 1993

Key words: Quaternary, limnogeology, Pampean laguna, sedimentology paleoenvironments, marine sediments

\begin{abstract}
Our sedimentological study of Lobos Lake sediments has shown that, below modern deposits, there is a clastic and biological record of three different paleoenvironments: two aquatic (freshwater and mixohaline respectively) and one subaereal. This record documents the climatic and geomorphologic changes that affected the basin during its evolution up to its present water level, from the upper Pleistocene to the Holocene.
\end{abstract}

\section{Introduction}

Few sedimentological studies of modern pampean 'lagunas' have appeared in the limnological lite-rature.

This paper, on the basis of geologic surveying in the Lobos Lake area, deals with the main sedimentary characteristics of this modern pampean 'laguna' basin, which are described in terms of vertical sedimentary sequences, textural facies and depositional environments. Furthermore, a reconstruction of the basin's development is presented, as it is useful not only for comparison with other Holocene 'lagunas', but also as an analogue to determine the origin of other Quaternary sequences.

\section{Geological setting}

Lobos Lake is an inland lake typical of the Pampean plains of Argentina. It is a permanent water body, regionally called 'laguna', corresponding to a third order

* This is the seventh in a series of papers published in this issue on 'Paleolimnology in Southern South America'. Dr. C. A. Fernández served as guest editor for these papers. or polymictic lake, on the basis of its continuos circulation and absence of thermal stratification.

The lake, at $22.6 \mathrm{~m}$ above sea level, covers an area of $7.6 \mathrm{~km}^{2}$. It is situated $115 \mathrm{~km}$ southwest of Buenos Aires City $\left(37^{\circ} 17^{\prime} \mathrm{S}\right.$ and $\left.59^{\circ} 07^{\prime} \mathrm{W}\right)$ in an aeolian plain of low relief and very gentle slope $(0.026 \%)$. The drainage system of Lobos Lake is $1720 \mathrm{~km}^{2}$, and is a tributary of the Salado River of Buenos Aires Province (Fig. 1 and 2).

The regional climate is humid temperate, with a mean annual temperature of $15.6^{\circ} \mathrm{C}$ and a regular distribution of the rainfall through out the year, with an annual mean of $902 \mathrm{~mm}$. However, the hydrographic network is poorly developed, with a $71.3 \mathrm{~km}$ long collector, Las Garzas Creek and sixteen tributaries, which compose only twenty-two channels with a drainage density of $0.126 \mathrm{~km} \mathrm{~km}^{-2}$. All these streams have been, to various extents, culturally modified. The lake is fed by rainfall and runoff. The seepage relationship with the groundwater regime has a double character (effluent - influent).

Water chemical characteristic show an oligohaline salinity range $\left(2 \mathrm{~g} \mathrm{I}^{-1}\right)$, with scarcely alkaline $\mathrm{pH}$, high total hardness (420 $\left.\mathrm{mg} \mathrm{l}^{-1}\right), \mathrm{Mg} / \mathrm{Ca}: 4.9$ and $\mathrm{Cl} / \mathrm{CO}_{3}+\mathrm{HCO}_{3}: 2.6$. The distinctive features of its 


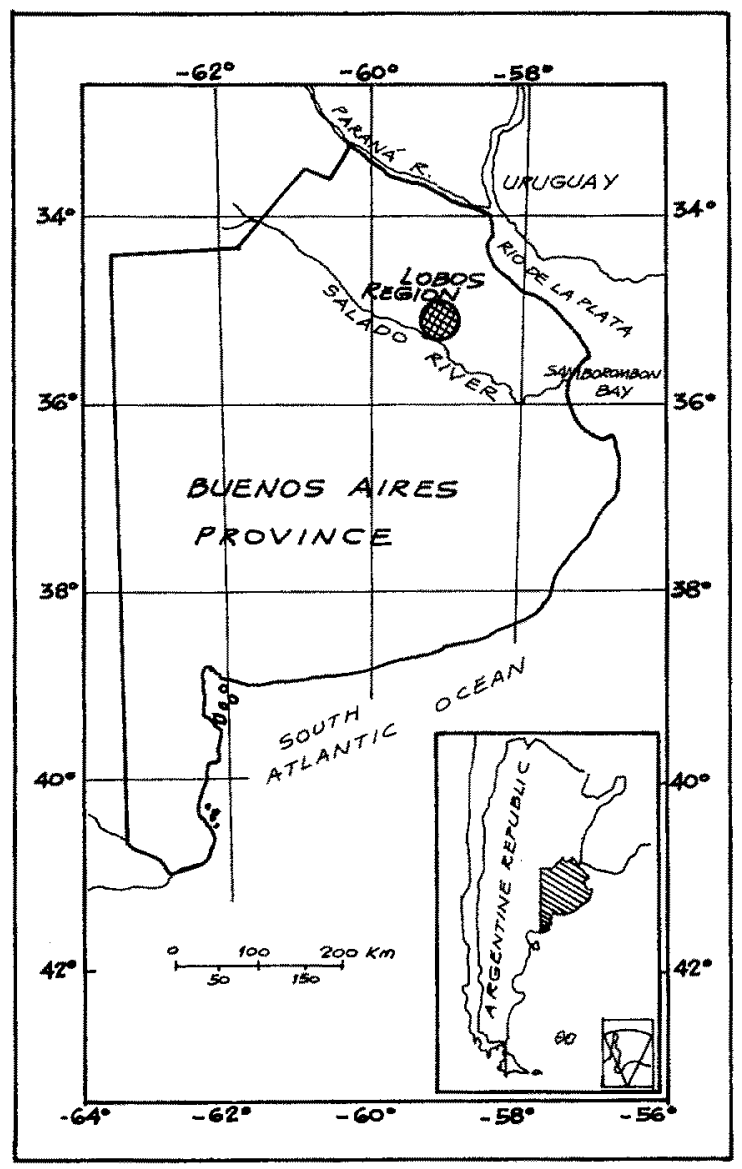

Fig. 1. Buenos Aires Province, Argentina. Lobos region location map.

chemical composition, according to Maucha's classification (Maucha, 1932) are: clorate sodic, sulfated, hemi to bicarbonated and hemi-magnesic water.

This aquatic environment is located in a basin ontologically related to hydrologic and aeolian processes with a progressive infilling of detrital and chemical materials. The initial 'wanne' shape was more than $7 \mathrm{~m}$ deep, but the present shallow 'pfanne' is only $2 \mathrm{~m}$ deep. Bluffs of variable heigth $(0.3$ to $4 \mathrm{~m})$ composed of upper and late Pleistocene and Holocene sediments, are found around its coastal perimeter.

\section{Stratigraphy}

The regional landscape is developed in Quaternary terrains, whose main outcrops are found along the lake bluffs. Four lithostratigraphic units have been recognized; three making up bluffs and one along the shore line (Fig. 4).

The oldest unit, correlated with the Ensenada Formation (Riggi et al., 1986) of middle Pleistocene age, constitutes the lake bedrock. This unit, which is a slightly to strongly consolidated and carbonated, laminated or massive sandy siltstone, crops out at basal bluff section and lake beaches.

The second unit, the Buenos Aires Formation (Riggi et al, op. cit.) of late Pleistocene age, is a loess mantle, 0.15 to $3 \mathrm{~m}$ thick, unconformably overlying the Ensenada Formation. It is mostly a friable sandy silt loess, containing scattered caliche nodules (Löesskindel).

The uppermost unit, the upper La Postrera Formation (Fidalgo, 1983), blankets the whole landscape. It is a Holocene vitroclastic loess mantle, up to $1 \mathrm{~m}$ thick, devoid of caliche nodules. Its thickness diminishes considerably below the alluvial deposits in the valleys outside the lake area. Present soils have developed on this unit.

The youngest subaereous unit in the area is the Alluvium, a discontinous, poorly sorted, gravelly to clayey sediment found in lake beaches and fluvial channels. Besides, it ocurrs as the major conspicuous alluvial deposit at the lake bottom, where it is more than $1.3 \mathrm{~m}$ thick, (Blasi \& Dangavs, 1992) (Fig. 4).

\section{Sedimentary and biological paleoenvironmental record of the lake basin}

The paleotopography of the primitive lake bed bassin and the vertical sedimentary sequences were studied from cores of 40 boreholes reaching a depth of more than $6 \mathrm{~m}$, which allowed us to analyze $5 \mathrm{~m}$ of infilling sediments, (Fig. 3).

The infilling sediments, constitute different superimposed sedimentary bodies (Fig. 4), which represent diverse paleoenvironmental depositional episodes that ocurred in the basin throughout the development to the present water body. Thus, below the modern lake sediments, we have found the clastic and biological record from three different paleoenvironments: two subaqueous (freshwater and mixohaline) and one subaereal.

All sedimentary sequences have been modified by post-depositional intra-sedimentary gypsum precipitation that occurred during the maximum desiccation episodes of the basin under semi-arid conditions (Dangavs \& Blasi, 1992a). 


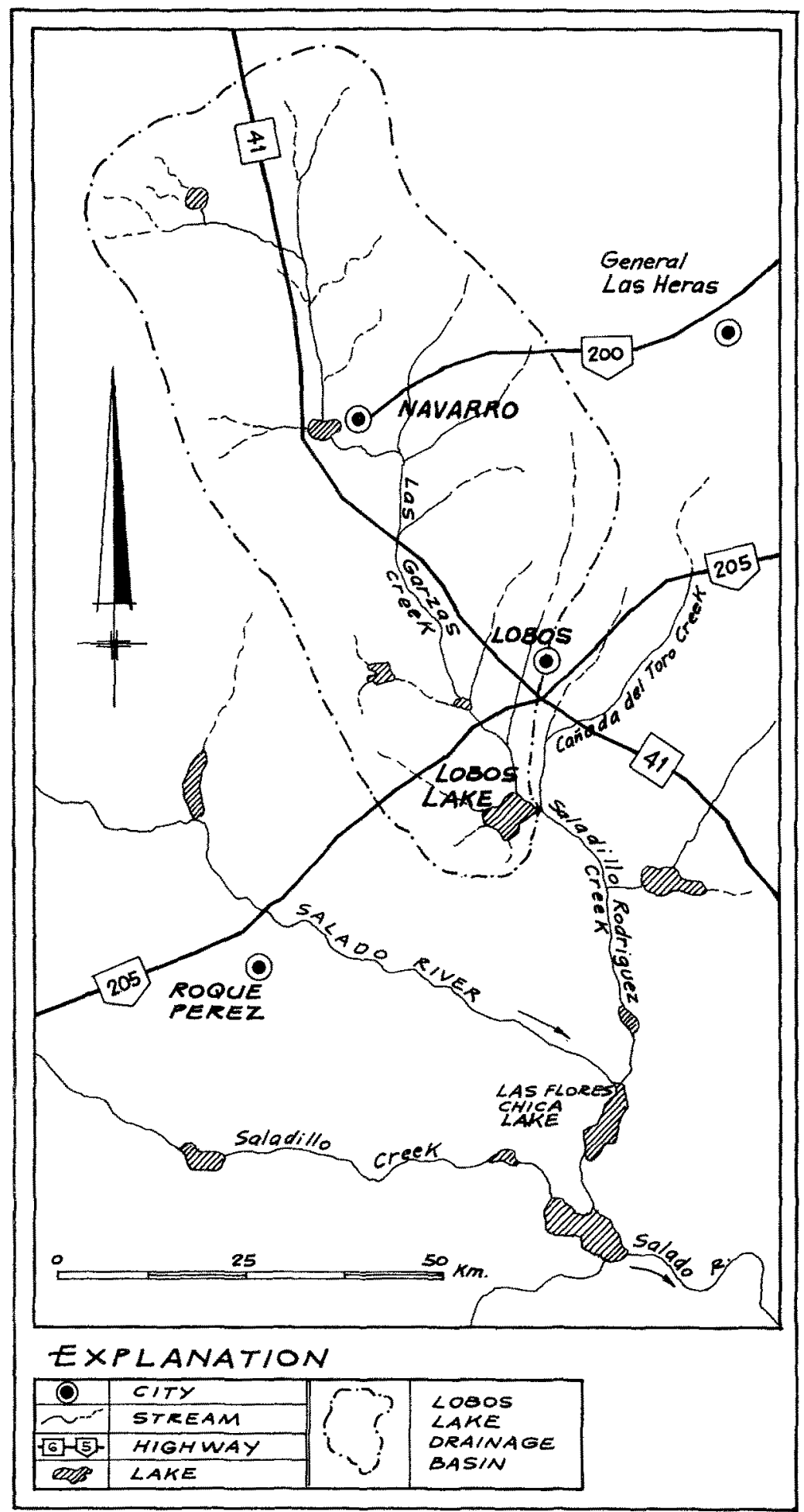

Fig. 2. Location map of Lobos Lake and its drainage basin. 


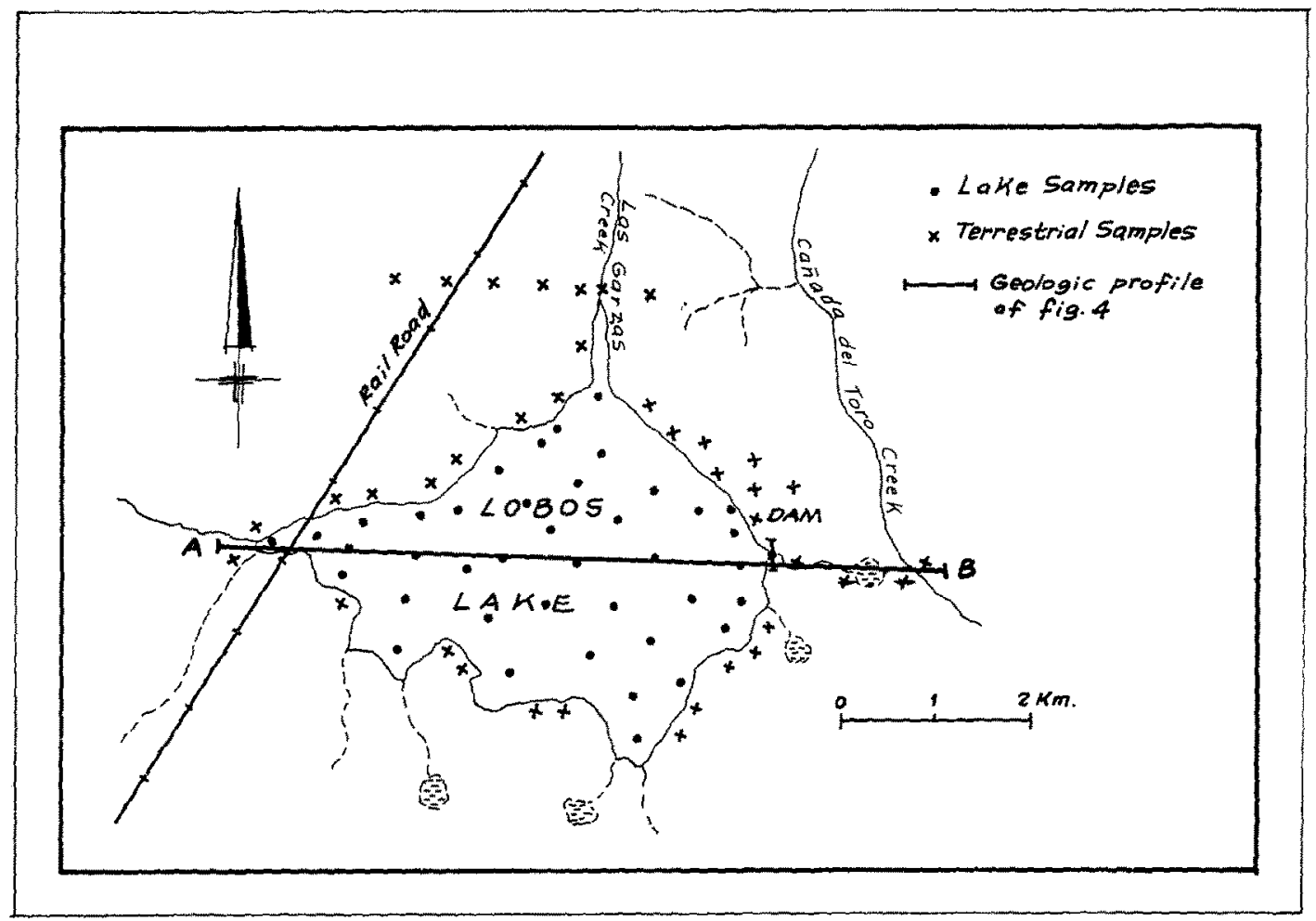

Fig. 3. Index maps of Lobos Lake Sample locations.

Sedimentary body 1 - Freshwater paleolentic deposit (mudstone facies)

Over the basinal bedrock are $2.9 \mathrm{~km}^{2}$ of freshwater paleolentic deposits, with a maximum thickness of $2.66 \mathrm{~m}$ and a volume of $3.1 \mathrm{hm}^{3}$. These are composed of grey to light grey silicoclastic mudstones ( $5 \mathrm{Y}$ $7 / 1-5 Y 6 / 1$ ), slightly hard to hard, bearing freshwater organic remains and abundant post-depositional lensshaped gypsum crystals.

The biological remains of the mudstones are:

\section{Gastropods}

Littoridina parchappei: adults and young; abundant. Ampullaria canaliculata: valve fragments; frequent to rare.

\section{Ostracods}

The same species found in present lentic environments of Buenos Aires Province. Adults and young. Left and right valves in the same proportions. Charophyta. Abundant.

Oogonia, calcified tubes and plates of the same origin; common.

\section{Diatoms}

Related to high vitroclastic ash contents. Rare in the sand fraction but abundant in the silt fraction.

Deposition of these sediments is related to subaqueous and partially subaereal processes during dessication periods, indicating waning water inputs and/or seasonally changing climates. Biological remains are similar to present lake organisms (i.e. oligohaline and alkaline indicators), but in lower numbers and much more broken. This evidence suggests that a marshy environment developed during the late Pleistocene.

Sedimentary body 2 - Subaereal paleonvironment (dessiccation surface and clay - pellets facies)

The more conspicuous deposits appears in the east sector, as an elongate eolian accumulation $1.7 \mathrm{~m}$ thick, which runs parallel to the present eastern coastline.

This dune is made up of sand-size, pellet-shaped clay-aggregates, light brown and light green, by break down of the lake's floor dry crust into sand-sized particles, and eolian accumulation due to the action of steady on-shore winds in the warm seasons with strong insolation. 
This depositional feature is associated with clear signs of weathering (such as strong bioturbation, ironoxide precipitation, abundant broken bioclasts and isolated clay pellets) in the upper $0.4 \mathrm{~m}$ of the surrounding paleolentic deposit.

Sedimentary body 3 - Mixohaline paleolentic deposits (siltstone and mudstone facies)

This deposit covers an area of $6.25 \mathrm{~km}^{2}$ with a maximum thickness of about $2 \mathrm{~m}$ and $9.7 \mathrm{hm}^{3}$ of total volume overlaying the Ensenada Formation, Sedimentary Body 2 (wheathering crust and clay dune), and Sedimentary Body 1 (paleolentic freshwater deposit).

Sedimentites are friable to hard sandy siltstones and sandy mudstones, pale-colored: yellowish-white to slightly green and gray, all in hue $10 \mathrm{YR}, 5 \mathrm{Y}$ and $2.5 \mathrm{Y}$.

The mudstone facies were affected by postdepositional intra-sedimentary gypsum precipitation in the form of sand size crystals with discoidal or lensshape grains or even as microrrosetes.

Epigenetic gypsum constitutes 34 to $56 \%$ of the mudstone facies, which cover an area of $3.22 \mathrm{~km}^{2}$. In the sandy siltstone facies, the gypsum content is very low due to the dissolution of crystals (Dangavs \& Blasi, 1992a).

Biological remains of this unit are:

Fish teeth, spines and vertebrae

\section{Gastropods}

A large amount of shells of diverse species, such as: Littoridina parchappei (d'Orbigny), abundant to frequent. Littoridina australis Pilsbry, common to frequent, that is dominant over $L$. parchappei near the present mouth. Littoridina conexa Gaillard, frequent to rare, only in ten samples. Littoridina australis crassa Gaillard is rare. Biomphalaria peregrina is frequent. Ampullaria sp. is frequent to rare. Succinea meridionalis is rare.

\section{Ostracods}

Abundant adults and young with both open and closed valves. Both valves in the same proportions. Typically freshwater forms, common in modern Buenos Aires Province inland waters. The major genera are Cypridopsis, Limnocythere and Elpidium. In smaller numbers there are closed valves with sculpture and valvular vaulting. In some samples, the ostracods replace Foraminifera and constitute an ostracod-mud.

\section{Foraminifera}

Abundant to rare. Present in all samples, but with low species diversity. They are generally large forms $(0.33$ $\mathrm{mm}$ ). Foraminifera taphanocoenosis is dominant in some sites and absolute in others. It is associated with marine organisms such as Littoridina australis, $L$. australis crassa and $L$. conexa. The taxonomic determinations made by nomenclatura aperta identify these species: Rotalia beccari parkinsoniana (d'Orbigny) abundant; Elphidium discoidale (d'Orbigny) frequent; Elphidium galvestonense Kornfeld rare; Bucella ex gr. frigida (Cushman) rare; Discorbis nitidus (f. praegeri) (Heron-Allen et Earland)? rare; Cornuspira planorbis Schultze very rare.

Generally the dominant genus is Rotalia, except in some samples where it is replaced by $E$. discoidale. Rotalia - E. discoidale - Bucella - and other species relationships are 92:6:1:1.

\section{Diatoms}

Frustules appear discontinuously in the sand fraction; finer sizes were not studied. Their presence is usually related to the vitric ashfall layers. We only identified some of the large forms: Surirella striatula Turpin, Campylodiscus clypeus Ehrenberg, Navicula sp., Caloneis sp., Coscinodiscus sp. and Anomoeoneis sp.

\section{Charophyta}

Oogonia are always present in samples, and especially common in sand-size samples. We could recognize three different types. Also, the gyrogonites were associated with calcium carbonate plates, tubes, branches and stems related to the calcified thalli of these algae.

Regarding the origin and salinity tolerance of these organisms, we have found freshwater and mixohalineeuryhaline (Segerstrale et al., 1959) species together. The Gasteropoda of marine lineage, like Littoridina australis (Pilsbury, 1911), live presently in the Rio de la Plata near Montevideo in an euryhaline habitat. Littoridina conexa is a typically estruary-lagoon form (Gaillard, 1974), and Littoridina australis crassa perhaps could be an ecological variety of $L$. australis. Among the Ostracoda, we have found freshwater and mixohaline species together, and perhaps calcareous and siliceous algae also.

Elsewhere, Foraminifera populations (Rotalia bec- 

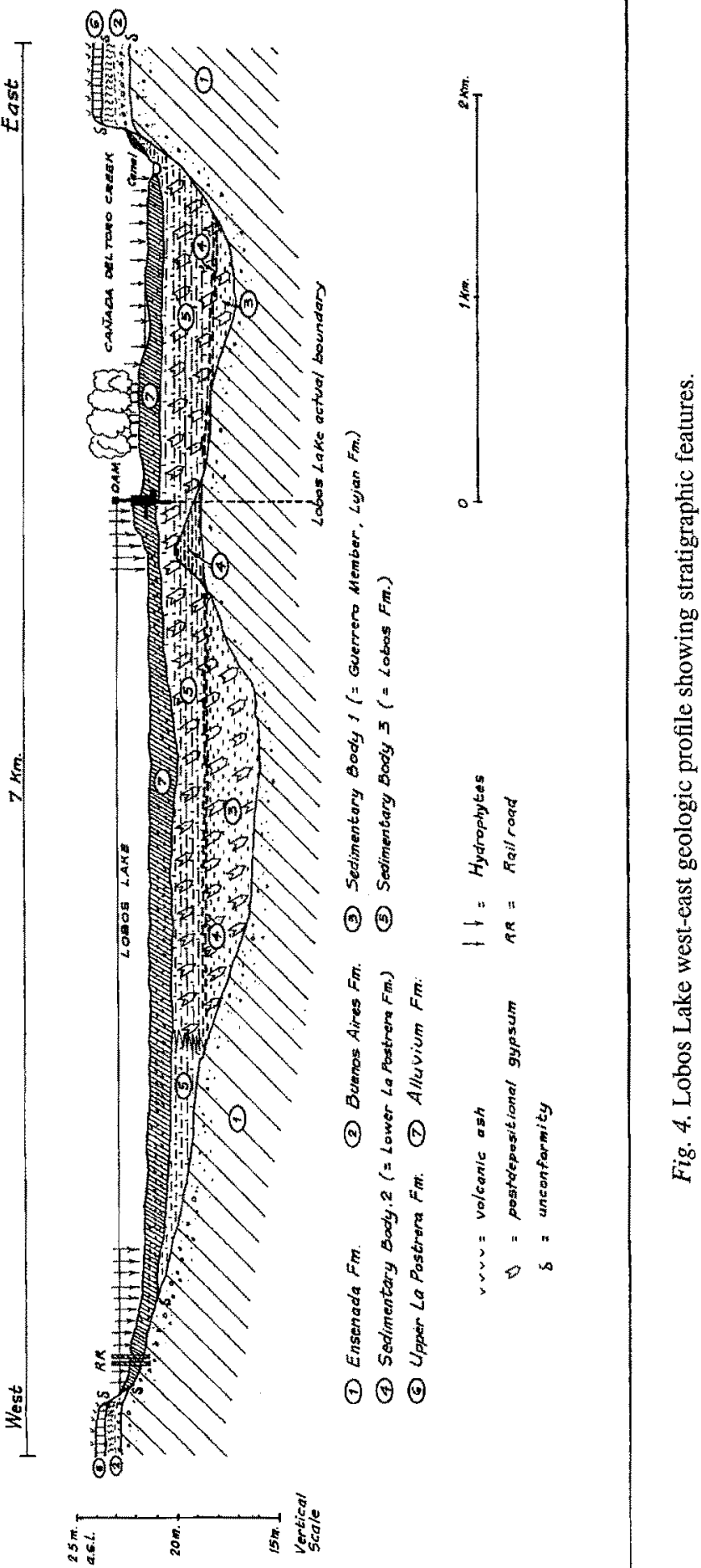
cari parkinsoniana, Elphidium discoidale) suggest a mixohaline environment, such as a tidal marsh or what Urien (1967) called a 'fluvio-marine zone' in the Rio de la Plata ([named later 'Rotalia beccari parkinsoniana biofacies zone' by Boltovskoy \& Lena (1974)].

Hence, the freshwater and mixohaline species mixture in Sedimentary Body 3 reveals the same habitat characteristics that occur in coastal lagoons, with salinity variations from oligo to mesohaline ranges. These may be related to a broader estuary of the Rio de la Plata that developed toward the south, when the Holocene marine transgression reached the ancient Lobos Lake.

Cann \& DeDeckker (1981), however, state for Australia the athalassic origin of this type of population, introduced by sea bird displacements into an environment where saline lakes made possible their survival and reproduction. Likewise, DeDeckker (1988) considers that the low species diversity of Foraminifera is typical of non-marine saline lakes. All these possibilities are not denied by our study, but in our opinion, based furthermore on considerable Pampean plain research, the arguments for direct marine influences are more likely. For example:

1. Modern lentic environment samples (fresh or brackish saline waters) never contain Foraminifera tests.

2. The existence of a fluvio-lacustrine watershed that formerly interconnected with the Río de la Plata estuary.

3. The regionally broad distribution of the mixohaline environment sediments.

4. The presence of surficial and related groundwater, whose ionic composition relationships $\left(\mathrm{Cl} / \mathrm{HCO}_{3}\right.$; $\mathrm{Mg} / \mathrm{Ca}$ ) suggest sea water influence.

5. The inland geographic location of these sediments is similar to those assigned by various authors to the Holocene Querendinense ingression.

6. The position above sea level (18.4 to 21.5 masl) is not compatible with a Holocene ingression, unless they are considered neotectonic events.

7. The presence of similar mixohaline sediments along the Salado River course up to the Las Flores Chica Lake latitude.

8. The low species diversity of the paleolake Forminifera benthos thaphanocoenosis is similar to the present assemblage in the Samborombon Bay coastal plain and Ajó River.

\section{Stratigraphic correlation}

Lithological and environmental characteristics allow us to place the Sedimentary Body 1 in a stratigraphic position near the Pleistocene-Holocene boundary, and correlate it with the Guerrero Member of the Luján Formation (Fidalgo, 1983). The overlying clay dune deposits of Body 2 belong to the lower La Postrera Formation (Fidalgo, op. cit.).

The overlying mixohaline deposits of Body 3 belong to the Lobos Formation (Dangavs \& Blasi, 1992b), and was deposited in the Holocene, with a probable age between 6000 to 7000 years B.P. It can be correlated with the Querandinense Transgression (Frenguelli, 1957). Both the Lobos Formation and Querandinense are lithostratigraphic records of estuarine channel deposits in the region along the Salado River up to $+15 \mathrm{~m}$ bench mark, i.e. $120 \mathrm{~km}$ west of the present Samborombón Bay coastline.

\section{Conclusions}

All the infilling sediments of Lobos Lake and the stratigraphic sequences of the surrounding terrain represent more than 0.1 million years between the upper Pleistocene and the Holocene.

Our sedimentologic study of Lobos Lake allows us to recognize a development of different environments during the Quaternary in response to climatic and geomorphologic changes, and the existence of an important stratigraphic hiatus between the Sedimentary Body 3 and the modern lake sediments, of about 5000 B.P. This hiatus imposes a great limitation on our paleoenvironment interpretations.

More research on the geological history of the surrounding sedimentary sequences is needed, which should include paleopedologic, paleohydrologic and paleoenvironmental data for elucidating the environmental history of Lobos Lake.

\section{Acknowledgements}

Our thanks to Comisión de Investigaciones Científicas of Buenos Aires Province, Argentina for their support of this project. We also offer our thanks to Drs John P. Smol and Mario E. Terrugi for their suggestions in reviewing this manuscript. 


\section{References}

Blasi, A. \& N. Dangavs, 1992. Sedimentos actuales de la laguna Lobos, Buenos Aires, Argentina. $4^{a}$ Reunión Argentina Sedimentología Actas II: 167-174. La Plata.

Boltovskoy, E. \& H. Lena, 1974. Foraminiferos del Río de La Plata. Publicación H 661 Servicio Hidrografia Naval, 22 pp. Buenos Aires.

Cann, J. \& P. DeDeckker, 1981. Fossil Quaternary and living Foraminifera from athalassic saline lakes, South Australia. J. Paleontol. 55: 660-670.

Dangavs, N. \& A. Blasi, 1992a. Presencia de yeso en Lobos, Buenos Aires, Argentina. Revista Museo La Plata, secc. Geol. X (in press).

DeDeckker, P., 1988. Biological and sedimentary facies of Australian salt lakes. Palaeogeogr., Palaeoclimatol., Palaeoecol. 62: 237-270.

Fidalgo, F, 1983. Algunas características de los sedimentos superficiales en la cuenca del ro Salado y en La Pampa Ondulada. Coloquio Internacional Hidrologia Grandes Llanuras, Olavarria. UNESCO. Actas II: 1043-1067. Buenos Aires.
Frenguelli, J., 1957. Neozoico. In: Geografía República Argentina GAEA. 2: 1-113. Buenos Aires.

Gaillard, M. C., 1974. Sobre nuevas Littoridina de la República Argentina. Neotrópica 20: 141-143.

Maucha, R., 1932. Hydrochemische Methoden in der Limnologie. Die Binnengewässer 12: 1-173. Stuttgart.

Pilsbry, H., 1911. Non marine Mollusca of Patagonia. Rep. Princeton University Expedition Patagonia, Zoology 5: 513-653.

Riggi, J., F. Fidalgo, O. Martinez \& N. Porro, 1986. Geología de los 'Sedimentos Pampeanos' en el Partido de La Plata. Asociación Geológica Argentina Revista 41: 316-333. Buenos Aires.

Segerstrale, S. et al., 1959. Simposio sulla classificazione della acque salmastre. Venezia 1958. Archivio Oceonografia e Limnologia XI, suppl. 243 pp. Italia.

Urien, C., 1967. Los sedimentos modernos del río de La Plata exterior. Boletin Servicio Hidrografia Naval 4: 113-213. Buenos Aires. 